\title{
Wyrok Sądu Metropolitalnego w Katowicach (c. Sobański) z 24 czerwca 2010 roku z tytułu niezdolności kobiety oraz/lub mężczyzny do podjęcia istotnych obowiązków małżeńskich
}

Artykuł został opracowany do udostępnienia w internecie przez Muzeum Historii Polski w ramach prac podejmowanych na rzecz zapewnienia otwartego, powszechnego i trwałego dostępu do polskiego dorobku naukowego i kulturalnego. Artykuł jest umieszczony w kolekcji cyfrowej bazhum.muzhp.pl, gromadzącej zawartość polskich czasopism humanistycznych i społecznych.

Tekst jest udostępniony do wykorzystania w ramach dozwolonego użytku. 


\section{WYROK SĄDU METROPOLITALNEGO W KATOWICACH (C. SOBAŃSKI) Z 24.6.2010 Z TYTUŁU NIEZDOLNOŚCI KOBIETY ORAZ/LUB MĘŻCZYZNY DO PODJĘCIA ISTOTNYCH OBOWIĄZKÓW MAŁŻEŃSKICH}

\section{Przebieg sprawy:}

MC oraz HR zawarli małżeństwo 31.03.1970 w kościele Matki Bożej z Lourdes w (...). Ważność tego małżeństwa zaskarżył MC 13.8.2004 w Sądzie Kościelnym w (...). Sprawa, prowadzona z tytułu niezdolności mężczyzny do podjęcia istotnych obowiązków małżeńskich oraz z tytułu niezdolności kobiety do podjęcia istotnych obowiązków małżeńskich, zakończyła się 5.2.2007 wyrokiem orzekającym, że udowodniono nieważność małżeństwa $\mathrm{z}$ obydwu rozpatrywanych tytułów. Zgodnie z kan. 1682 §1 sprawa znalazła się w Trybunale apelacyjnym, tj. w Metropolitalnym Sądzie w (...). Sędziowie Trybunału apelacyjnego postanowili rozpatrywać sprawę zwyczajnym trybem postępowania. Dnia 20.5.2009 orzeczono, iż nie udowodniono nieważności małżeństwa, a tym samym uchylono w całości wyrok Trybunału I Instancji. Na popartą przez Arcybiskupa (...) prośbę powoda Najwyższy Trybunał Sygnatury Apostolskiej reskryptem z 10.10.2009 wyznaczył Sąd Metropolitalny w Katowicach do rozpatrzenia sprawy w III Instancji. Akta sprawy nadeszły 7.12. i 21.12.2009. Strony nie przedłożyły nowych wniosków dowodowych. Przedmiotem sprawy jest (czy) było pytanie, czy udowodniono nieważność małżeństwa z tytułu niezdolności kobiety oraz/lub mężczyzny do podjęcia istotnych obowiązków małżeńskich.

\section{Faktyczny stan sprawy:}

W rozpatrywanej sprawie konieczne jest wyjaśnienie elementarnych pojęć. Powód wniósł o orzeczenie nieważności małżeństwa z tytułu niezdolności do podjęcia i wypełnienia istotnych obowiązków 
małżeńskich na skutek braku dojrzałości i odpowiedzialności po stronie pozwanej oraz (co dopisano ręcznie) powodowej. To twierdzenie o niezdolności powodowanej brakiem dojrzałości nie zostało poparte w skardze ani słowem! Wbrew stwierdzeniu zawartemu w dekrecie przyjmującym skargę, nie spełnia ona wymogów określonych kan. $15042^{\circ}$.

Co więcej, twierdzenie o niezdolności powodowanej czynnikami psychicznymi nie znalazło żadnego oparcia w zeznaniach stron. Zeznania powoda przytoczone w wyroku Trybunału I Instancji nie pozostają w żadnym związku z tytułem sprawy (co wspólnego z niezdolnością psychiczną mają kontakty pozwanej z ,poprzednim” chłopakiem?) i nie wiadomo, dlaczego je przytoczono.

Pozwana przyznaje: „Zbyt pochopnie podjęliśmy decyzję o rozejściu się, nie uczyniliśmy wszystkiego, aby utrzymać wspólnotę małżeńską". Rozczarowanie pożyciem małżeńskim spowodowało wygaśnięcie jej uczuć względem powoda, a ,szybkie zawarcie następnego związku małżeńskiego przez powoda uniemożliwiło jej naprawienie małżeństwa".

W referowanych w wyroku I Instancji jako, ,faktyczne podstawy orzeczenia", informacjach dostarczonych przez strony trudno znaleźć jakiekolwiek przesłanki twierdzenia o defektach psychicznych czy osobowościowych stron. W motywacji prawnej wyroku przypomniano wprawdzie, że o zaburzeniach osobowości jako przyczynie niezdolności do małżeństwa można mówić wtedy, gdy są ciężkie, jednak zeznania zarówno stron jak też - konsekwentnie - świadków nie pozwalają dostrzec zaburzeń osobowości czy to powoda, czy to pozwanej (także w przytoczonych w wyroku zeznaniach świadków nie ma niczego, co mogłoby nasunąc podejrzenie ich istnienia).

Biegły psychiatra po rozmowie z powodem wypowiedział się zdecydowanie: „Stwierdzam, że był on zdolny do podjęcia i wypełnienia obowiązków małżeńskich". Sędziowie Trybunału I Instancji nie zgadzają się z tym wnioskiem, uważając, że biegły ,nie przeanalizował wystarczająco wszystkich okoliczności trwania małżeństwa i przyczyn jego rozpadu". Sędziowie, niestety, nie sprecyzowali tego zarzutu, nie wskazali, o jakie okoliczności mogłoby tu chodzić. Zamiast uzasadnienia zasygnalizowali, że biegły ,zasugerował się aktualnym stanem intelektualnym powoda".

Z kolei odnośnie do opinii dotyczącej pozwanej, o której biegły nie badawszy jej - pisze, że miała ograniczoną zdolność do wypełniania obowiązków małżeńskich, sędziowie I Instancji nie tylko nie 
zawahali się zaakceptować jej, ale uznali, że „negatywne cechy tej osobowości czyniły pozwaną niezdolną do budowania partnerskich więzów małżeńskich". Niestety, nie wiadomo, o jakie cechy chodzi, bo przecież trudno przypuścić, by Trybunał uznał za takie to, że pozwana „była osobą dość egzaltowaną”, o romantycznej i roszczeniowej wizji małżeństwa (u osoby, o której sędziowie przyznają, że ,z domu rodzinnego wyniosła przekonanie, że w małżeństwie trzeba się poświęcić dla dobra męża i rodziny”!). Również „wady osobowości" nie są sprecyzowane ani nawet nazwane, a dowodem na to, że „występowały w stopniu ciężkim”, ma być to, że pozwana „nie potrafiła ich skorygować". Twierdzenie o owych wadach ma więc charakter sądu a priori. Aprioryczny charakter twierdzeń wysuniętych na orzeczenie niezdolności psychicznej stron uwidacznia się wyraziście we wniosku wyciągniętym przez Trybunał I Instancji z krótkiego trwania (dziewięć miesięcy) wspólnoty małżeńskiej. Napisano: „Trudno bowiem przyjąc hipotezę, że dwie dojrzałe i psychicznie silne osoby w tak krótkim czasie nie potrafią znaleźć wspólnego języka i bez obiektywnie poważnych przyczyn zewnętrznych porzucą wspólne życie". Jest odwrotnie: właśnie założenie, iż krótkie trwanie wspólnoty dowodzi niezdolności (obu stron?) do trwania w małżeństwie, to hipoteza wymagająca udowodnienia, sprzeczna z domniemaniem ważności małżeństwa. Nie można też przyjąć argumentacji powoda zawartej w piśmie z 29.1.2010, że skoro trwałość małżeństwa nie była dla pozwanej czymś ważnym, to nie była ,wystarczająco psychicznie przygotowana do podjęcia wezwań z tym że wiążących". Wywody takie mijają się z przedmiotem sprawy.

Sąd zgadza się z konkluzją Trybunału II Instancji, że stronom zabrakło woli rozwiązywania problemów, co też przyznaje pozwana. Praktycznie znaczy to, że rychło po ślubie stron szwankowała wola wypełniania obowiązków małżeńskich. Powód napisał o sobie w skardze, że „niewątpliwie" zawierał małżeństwo „z miłości i chętnie”, a wyniesione $z$ domu wychowanie idealistyczne przenosił ,na grunt relacji z pozwaną". Również pozwana zeznała, że zawierała małżeństwo z miłości, a chociaż ,z domu rodzinnego wyniosła dość złożone wzorce”, to jednak „odebrała jasne postawy moralne”. Z tych stwierdzeń wynika, że wola stron zawierających małżeństwo była autentyczna i szczera (i nie została ona zakwestionowana). Zgodnie $z$ teza powództwa należałoby postawić, a następnie udowodnić hipotezę, że tej woli nie odpowiadały możliwości osobowościowe stron, ale brak ja- 
kichkolwiek argumentów na poparcie tej hipotezy, brak ich nie tylko w obiektywnych dowodach, ale nawet w zeznaniach stron, łącznie z zeznaniami i pismami powoda.

Słusznie przypomniano w motywacji prawnej wyroku Trybunału II Instancji, że przedmiotem sprawy nie jest faktyczne wywiązywanie się stron z obowiązków małżeńskich, lecz akt woli konstytuujący małżeństwo, w tym przypadku: czy był to akt woli osób zdolnych podjąć obowiązki małżeńskie. Domniemanie prawne przemawia za zdolnością do wypełnienia tych obowiązków, udowodnić trzeba przeto niezdolność do ich wypełnienia: kto nie jest zdolny wypełnić, tym samym nie jest zdolny podjąć, gdyż nikt nie może zobowiązywać się do czegoś, czego nie jest w stanie wykonać. Wobec stanu akt sprawy wymaga wyjaśnienia pojęcie niezdolności, o której w kan. 1095 n. 3, będącym prawną podstawą rozpatrywanej sprawy.

\section{Motywy prawne:}

Podstawą prawną rozpatrywanej sprawy jest kan. 1095 n. 3, który brzmi: „Niezdolni do zawarcia małżeństwa są ci, którzy: ... z przyczyn natury psychicznej nie są zdolni podjąć istotnych obowiązków małżeńskich”. Przymiotnik ,niezdolni” jest przekładem łacińskiego ,incapaces", użytego w oryginalnym wydaniu Kodeksu Prawa Kanonicznego. Nazwę „capacitas” stosuje się na określenie wymogów prawa naturalnego (capacitas actus humani), w odróżnieniu od „habilitas” oznaczającej zdolność określoną przez prawo. W polskim tłumaczeniu kan. 1095 n. 3 wyraz ,niezdolność” występuje dwukrotnie: „,niezdolni” (incapaces) i „nie są zdolni” (,non valent”). Zgodnie z tą normą niezdolni (i to z prawa naturalnego) do zawarcia małżeństwa są ci, którzy są niezdolni do wypełnienia istotnych obowiązków małżeńskich. Rozstrzygnięcie rozpatrywanej sprawy wymaga wyjaśnienia tej właśnie niezdolności.

Niezdolność, o której w kan. 1095 n. 3, jest równoznaczna z niemożliwością, powodowaną przyczynami natury psychicznej, do podjęcia (a w konsekwencji do wykonania) istotnych obowiązków małżeńskich: nupturient nie jest zdolny do przekazania przedmiotu konsensu małżeńskiego. Niezdolność ta polega więc na tym, że nupturient, aczkolwiek zdolny do prawidłowego wyrażenia konsensu, to jednak z powodu jakiejś anomalii psychicznej lub zaburzeń osobowości nie jest zdolny podjąć (i wykonać) któregoś (lub żadnego) z istotnych 
obowiązków małżeńskich. Istotne obowiązki to nie tylko te, które są następstwem istotnych przymiotów małżeństwa, tzn. jedności i nierozerwalności (kan. 1056), lecz te, które nieodłącznie mieszczą się w pojęciu małżeństwa jako „wspólnoty całego życia, skierowanej ze swej natury do dobra małżonków oraz do zrodzenia i wychowania potomstwa" (kan. $1055 \S 1$ ).

Niezdolność trzeba odróżnić od braku dobrej woli wypełniania obowiązków małżeńskich: nie wystarcza wykazać faktyczne ich niewypełnianie, lecz trzeba wykazać, że przyczyny tego tkwiły w psychice nupturienta. „Kanonista winien kierować się jednoznaczną zasadą, że tylko niezdolność, a nie trudności w zakresie zgody małżeńskiej i urzeczywistnienia prawdziwej wspólnoty życia i miłości, powoduje nieważność małżeństwa. Załamanie się jakiegoś związku małżeńskiego nigdy samo w sobie nie może stanowić dowodu służącego wykazaniu owej niezdolności kontrahentów, którzy mogli zaniedbać lub używać źle będące do ich dyspozycji środki zarówno naturalne, jak nadprzyrodzone, bądź też nie zaakceptować nieuniknionych ograniczeń lub ciężarów życia w związku małżeńskim" (Jan Paweł II, przemówienie z 5.2.1987).

Przedmiot rozpatrywanej sprawy określono jako niezdolność obu stron do podjęcia istotnych obowiązków małżeńskich. Znaczy to, że należało udowodnić niezdolność - czyli anomalie lub zaburzenia natury psychicznej - zarówno powoda, jak i pozwanej. Nieważność małżeństwa powoduje już niezdolność wykazana u jednej ze stron.

Aby orzec nieważność małżeństwa Sąd musi osiągnąć moralną pewność co do istnienia faktycznych, uznanych jako takie przez prawo, podstaw nieważności. Twierdzenie moralnie pewne to takie, które opiera się na poważnych, przejrzystych podstawach, nie dopuszczających sensownych argumentów przeciwnych.

Zreferowany wyżej materiał dowodowy nie pozwala Sądowi osiągnąc moralnej pewności ani co do niezdolności mężczyzny ani co do niezdolności kobiety do podjęcia istotnych obowiązków małżeńskich. Tak więc Sąd odpowiada przecząco na pytania procesowe i orzeka, że nie udo wodni o no nieważności małżeństwa z żadnego z rozpatrywanych tytułów. 